Available online at: http://ejournal-balitbang.kkp.go.id/index.php/iaj

\title{
THE EFFECTS OF AN ARTIFICIAL COMMERCIAL FEED SUPPLEMENTATION ON LARVAL REARING AND CRABLET PRODUCTION OF MUD CRAB Scylla tranquebarica
}

\author{
Gunarto\#, Muhammad Nur Syafaat, Herlinah, Sulaeman, and Muliani \\ *) Research Institute for Coastal Aquaculture and Fisheries Extension \\ (Received 23 November 2017; Final revised 25 January 2018; Accepted 25 January 2018)
}

\begin{abstract}
The effects of an artificial commercial feed supplementation on larval rearing and crablet production of mud crab Scylla tranquebarica. In mass production of mud crab seeds, only rotifer and Artemia nauplii are usually fed to mud crab larvae rearing until the larvae develop to crablet stage. The supplementation of artificial commercial feed from zoea-3 stage is expected to supply an essential nutrient required for an optimum larval development. The research was aimed to determine the optimum dosage of commercial feed supplementation for a successful larval rearing to produce crablet in hatchery. Newly hatched larvae of mud crab were stocked at a density of 100 ind./L. The larvae were fed with rotifer and Artemia nauplii. Microbound artificial commercial feed sized $<100$ microns (protein $52 \%$ fat $14,5 \%$ fiber $3 \%$ and water content $10 \%$ was supplemented to the larvae from zoea-3 to megalopa stage at different dosages namely: a). $0.5 \mathrm{mg} / \mathrm{L} / 2$ days; b). $0.75 \mathrm{mg} / \mathrm{L} / 2$ days; c). $1.0 \mathrm{mg} / \mathrm{L} / 2$ days; d). $1.25 \mathrm{mg} / \mathrm{L} / 2$ days. Larval population, larval development indices (LDI), megalopa occurrence index (MOI) and crablet production were observed and measured. Water quality (ammonium, nitrite, Total Organic Matter (TOM), and total Vibrio sp. count were also monitored. The LDI, MOI, and crablet production from each treatment were compared and tested using one way-ANOVA. The results showed that the survival rate of larvae at zoea-5 ranged between 29$33 \%$ The LDI was not significantly different $(P>0.05)$ among treatments. However, the $\mathrm{MOI}$ of treatment $\mathrm{A}$ and $B$ at day 21 ph was significantly higher $(P<0.05)$ compared with treatment $C$ and $D$. In addition, the crablet production in treatment $B, C$ and $D$ were significantly higher $(P<0.05)$ compared with treatment $A$. It was concluded that the supplementation of artificial commercial feed in larval rearing of $\mathrm{S}$. tranquebarica could be applied at the dosage range of $0.75-1.25 \mathrm{mg} / \mathrm{L} / 2$-days from zoea-3 until crablet (C-7) stage.
\end{abstract}

\section{KEYWORDS: dosage; mangrove crab; Scylla tranquebarica; supplemented feed}

\section{INTRODUCTION}

Mud crab, Scylla spp. is known as an economically important species in the Asia Pacific countries where most of the market demand is supplied from its wild stock (Keenan, 1999; Ikhwanuddin et al., 2010). As a result, declines in catches have been reported from several mud crab resource areas (Thirunavukkarasu et al., 2014). Therefore, the hatchery technology for seed production of Scylla spp. needs to be developed in order to provide crablet (mud crab seed) for wild stock recovery program and mud crab culture in brackishwater pond. Unfortunately, the crablet pro-

\footnotetext{
\# Correspondence: Institute for Coastal Aquaculture Research and Fisheries Extension. Jl. Makmur Dg. Sitakka No. 129, Maros, South Sulawesi 90512, Indonesia.

Phone: + 62411371544

E-mail: gunartom@yahoo.com
}

duction from mud crab hatcheries in Indonesia is inconsistently varied due to factors such as low larvae vitality, unsynchronizing of zoea-5 metamorphosis to megalopa stage, and cannibalization of megalopa on zoea-5 larvae. Eventually, the cannibalization has resulted in only a small number of megalopa succeeded reaching crablet stage (Suprayudi et al., 2012).

In larval rearing, mud crab larvae commonly fed on rotifer, Brachionus plicatilis and Artemia nauplii only (Chen \& Cheng, 1985; Quinitio et al., 2001; Baylon, 2011; Anuar et al., 2011). The low contents of DHA and EPA in rotifer and Artemia are thought to be the cause of the low vitality of the larvae (Watanabe et al., 1983). Therefore, the enrichment of rotifer and Artemia nauplii with DHA and EPA is expected to improve larvae vitality (Hamasaki et al., 2002; Truong et al., 2007b; Gunarto \& Herlinah, 2015). 
The acceptance of mud crab larvae on food based on the particle size of the food is increased with age (Genodepa et al., 2004). Besides that, total digestive enzyme activities increased in correlation with the development of larvae digestive systems (Jonhston et al., 2004; Serrano, 2012) and the capability to digest food in larvae stomach. Based on the physical and physiological development of mud crab larvae, some evidence suggest that larvae at zoea-3 stage can accept artificial feed for their diets. The authors' earlier research on mud crab larvae rearing, only rotifer and Artemia nauplii enriched using HUFA (highly unsaturated fatty acid) were fed to the mud crab larvae without supplementation of artificial feed (Gunarto \& Herlinah, 2015; Gunarto et al., 2016). However, Holme (2008) conducted a study where an artificial feed (microbound feed size $<100$ microns) was supplemented to provide an essential nutrition needed by larvae for their growth and development. His study showed that the combination between microbound diet (MBD) and Artemia nauplii at a ratio of 50:50\%resulted in a higher larval survival rate compared with the larvae given either $100 \%$ of Artemia nauplii or MBD only. This research was aimed to determine the optimum dosage of microbound commercial feed for the successful larval rearing of mud crab, S. tranquebarica to produce crablet in the hatchery.

\section{MATERIALS AND METHODS}

The research was conducted at the wet Laboratory of Marana Research Station, the Research Institute for Coastal Aquaculture and Fisheries Extension, Maros, South Sulawesi, Indonesia from April to June 2016. In total, 12 circular conical tanks of $250 \mathrm{~L}$ each was filled with $200 \mathrm{~L}$ sterilized saline water with a salinity of $30 \mathrm{ppt}$. Healthy mud crab larvae indicated by active swimming on the water column were stocked in each tank with a density of 100 ind./L. Larvae from zoea-1 to zoea-2 were fed with rotifer (Brachionus plicatilis) enriched with HUFA at a density of $20-25 \mathrm{ind}$./ $\mathrm{mL}$. After larvae attained to zoea-3 stage, the diet was changed to Artemia nauplii enriched with HUFA and Nannochloropsis sp. Artemia nauplii was given at the density 3-5 ind./mL and it was continuous untill larvae attained megalopa stage. The HUFA enrichments of rotifer and Artemia nauplii used dosages of $20 \mathrm{mg} / \mathrm{L}$ and $200 \mathrm{mg} / \mathrm{L}$, respectively. Artemia nauplii were enriched with Nannochloropsis sp at a density $636 \times 10^{4} \mathrm{cell} / \mathrm{mL}$ (Gunarto \& Herlinah, 2015). The microbound commercial feed sized $<100$ microns (protein $52 \%$ fat $14.5 \%$ fiber $3 \%$ and water content $10 \%$ was supplemented to the larvae from zoea- 3 to megalopa stage at different dosages namely: A). 0.5 $\mathrm{mg} / \mathrm{L} / 2$ days, B). $0.75 \mathrm{mg} / \mathrm{L} / 2$ days, $\mathrm{C}) .1 .0 \mathrm{mg} / \mathrm{L} / 2$ days, and $D) .1 .25 \mathrm{mg} / \mathrm{L} / 2$ days.

Water was exchanged at a rate of 10 to $50 \%$ of the total water in the larval rearing tank started at day 7 post-hatching (ph) until day $27 \mathrm{ph}$. The larvae populations from zoea-1 to zoea-5 were monitored by taking 20 ind. of larvae as a sample from each tank for observation under a microscope to monitor larvae development. The larvae developmental stage was determined based on the number of plumose setae and the length of pleopod on the abdomen (Figure 1). Larval Development Indices (LDI) were calculated based on the criteria adopted from Truong et al. (2007a) by given a score to every stage of larvae. For instance larvae stage of zoea-1 was scored 1 , then larvae stage of zoea-2 was scored 2 , it was continues until larvae stage of zoea-5 was scored 5 and megalopa stage was scored 6 . In example from 20 individual of larval sampled were taken from the rearing tank, there were consisted of 10 indivual of larval at stage of zoea 3, then 6 individial of larval at stage of zoea 4, and 4 individual of larval at stage of zoea-2. The LDI values was calculated as performed in below:

$$
L D I=\frac{3 \times 10+4 \times 6+2 \times 4}{20}=\frac{62}{20}=3.1
$$

The populations of larvae zoea-5 and megalopa stage were separated (thinning) into two or three tanks to reduce the occurrences of cannibalism.

Megalopa Occurrences Indices (MOI) was also monitored from the first to the fifth days after the occurrences took place in the thinning tanks. The $\mathrm{MOI}$ values were calculated based on the occurrences of megalopa per 100 individual of zoea-5 in the thinning tank. The activity of amylase, lipase, and protease enzyme for each larvae stage were examined based on the procedure used by Serrano and Traifalgar (2012). Water quality parameters (ammonium, nitrite, Total Organic Matter and total Vibrio sp.) were measured once a week by collecting $500 \mathrm{~mL}$ water sample taken from each tank and analyzed in the laboratory following the procedure adopted from Clesceri et al. (2005). The data of LDI, MOI, and crablet production among the treatments were compared and tested using variance analysis with Completely Randomized Design (one-way ANOVA) and continued with the Turkey Test $(\alpha=0.05)$ whenever any significant difference among the treatments was found. IBM-SPSSStatistics v.24 software was used in the statistical analyzes. Data on water quality parameters were descriptively presented. 


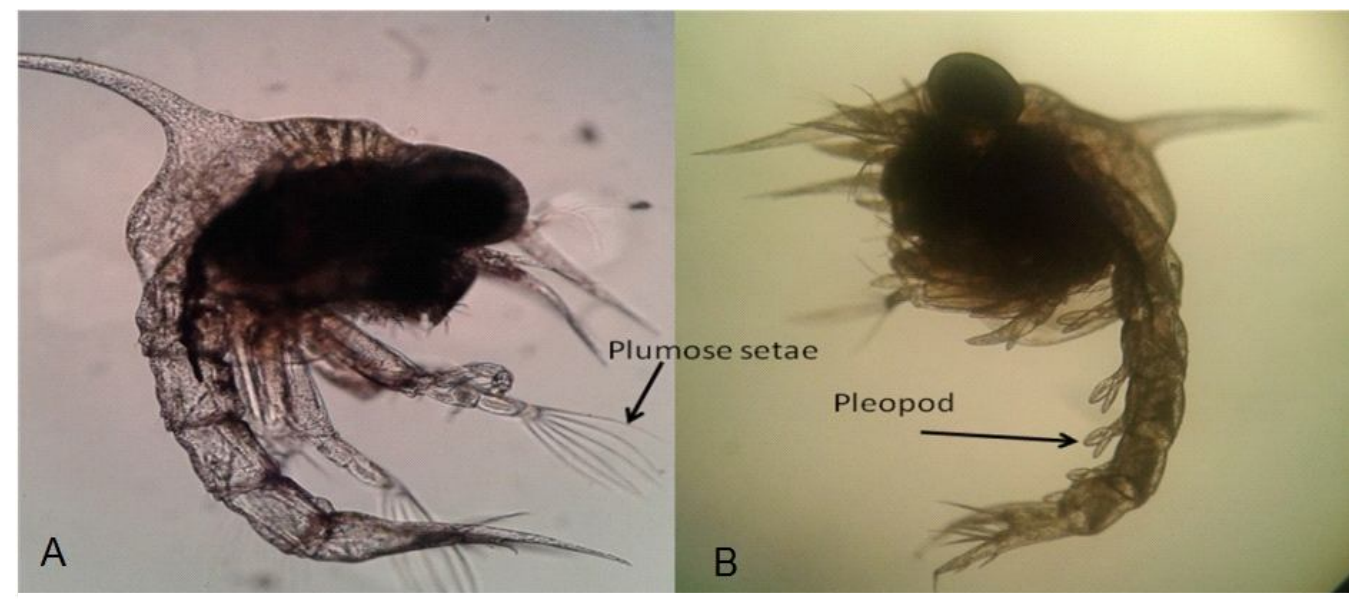

Figure 1. Larvae of zoea-2 with six of plumose setae (A) and larvae zoea-5 with long pleopod (B).

\section{RESULTS AND DISCUSSION}

\section{Larval Development}

The larval development is influenced by many factors such as the health condition of larvae and the presence or absence of parasitic organisms. Feeding in sufficient quantity and quality and good water quality can support the development of larvae as well. Based on the daily observation, the larvae of zoea-1, zoea- 2 , and zoea-3 were characterized by the formation of 4,6 , and 8 plumose setae, respectively. Zoea4 larvae were characterized with a short pleopod on the abdomen in addition to 10 plumose setae. Zoea5 has the same shape with zoea-4, but with a longer pleopod on the abdomen. The transformation period of zoea-1, zoea-2, zoea-3, zoea-4, and zoea-5 took place during day 1-8 ph, day 4-13 ph, day 7-17 ph, day 10-17 ph, and day 13-20 ph, respectively. Larval transformation to megalopa started at day 19 ph and then from megalopa to crablet stage started at day $26 \mathrm{ph}$ (Table 1). The development rate of larvae to crablet in this study is faster than authors' previous research in which the larvae fed with supplemented microbound diet at a dosage of $0.25-1.0 \mathrm{mg} / \mathrm{L}$, reached crablet stage at day $28 \mathrm{ph}$ (Gunarto \& Sulaeman, 2017).

The daily observation on larvae development showed unsynchronized transformation from one to another stage among individual larvae. As a result, the duration of every larval stage was longer (up to 7 days) compared with the duration of the normal developmental stage (Table 1 ). In this research the duration in each stage to develop to the consecutive stage was required varies days, namely zoea- 1 to zoea2, zoea-2 to zoea-3, zoea-3 to zoea-4, zoea-4 to zoea5 , zoea-5 to megalopa stage were required $7,9,10$, 8 , and 7 days respectively. These are much longer compared to the normal development of S. olivacea larvae from stage of zoea-1 to zoea-2, zoea-2 to zoea-3, zoea-3 to zoea-4, zoea-4 to zoea-5, and zoea5 to megalopa, reported only required at $6,4,3,4,5$ days respectively (Gunarto et al., 2016).

Larvae populations in all treatments had decreased by $50 \%$ from zoea- 1 to zoea-2 stage. Insufficient live feed provided in these periods (rotifer given as feed with a density of only $20 \mathrm{ind} . / \mathrm{mL}$ ) was probably the reason for this high mortality. Truong et al. (2007a) reported that larvae fed with rotifer at a density of $45 \mathrm{ind}$. $/ \mathrm{mL}$ had higher survival rate compared to larvae fed with rotifer at a density of $60 \mathrm{ind} . / \mathrm{mL}$. The larvae populations were variably dropped when reaching zoea-3 stage up $9.75 \%$ 5.5\% $14.6 \%$ and $8.3 \%$ for $A, B, C$, and D treatments, respectively. From zoea-3 to zoea-4, the larvae populations continuously decreased differently by $1.8 \% 2.4 \% 0.6 \%$ and $3.6 \%$ for $A, B, C$, and D treatments, respectively. From zoea- 4 to zoea-5, the larvae dropped in the percentage of survival rate by $5.4 \%(A), 9.1 \%(B), 3.0 \%(C)$, and $3.7 \%$ (D) (Table 2). The mortality rates of larvae during their development from zoea-3 to zoea- 4 and zoea-4 to zoea-5 were relatively low. This result indicates that food combination between Artemia nauplii and artificial feed is suitable to minimize mortality. Truong et al. (2007a) reported that the handling procedures of mud crab larvae at different stages from zoea- 3 to zoea-5 need to be adjusted especially related to the species, feed size, larvae status, technique, and larval rearing systems. The larvae survival rate until stage of zoea- 5 in all treatments in this study ranged between 29 to $32 \%$ and statistically analysis there were showed no significantly difference $(P>0.05)$ among treatments (Table 2). 
Table 1. Mud crab S. tranquebarica larvae development based on the characteristic developed by Gunarto et al. (2016)

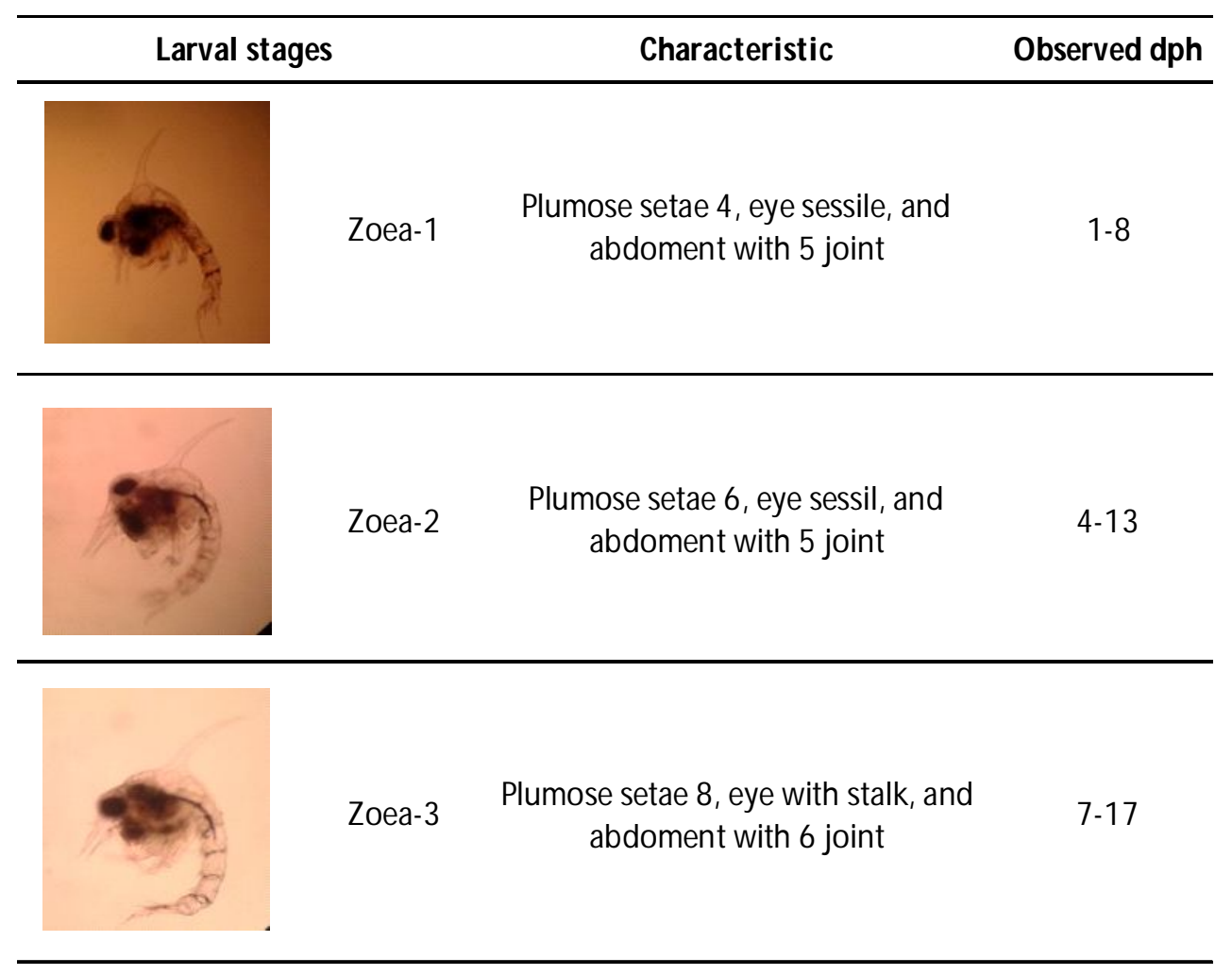
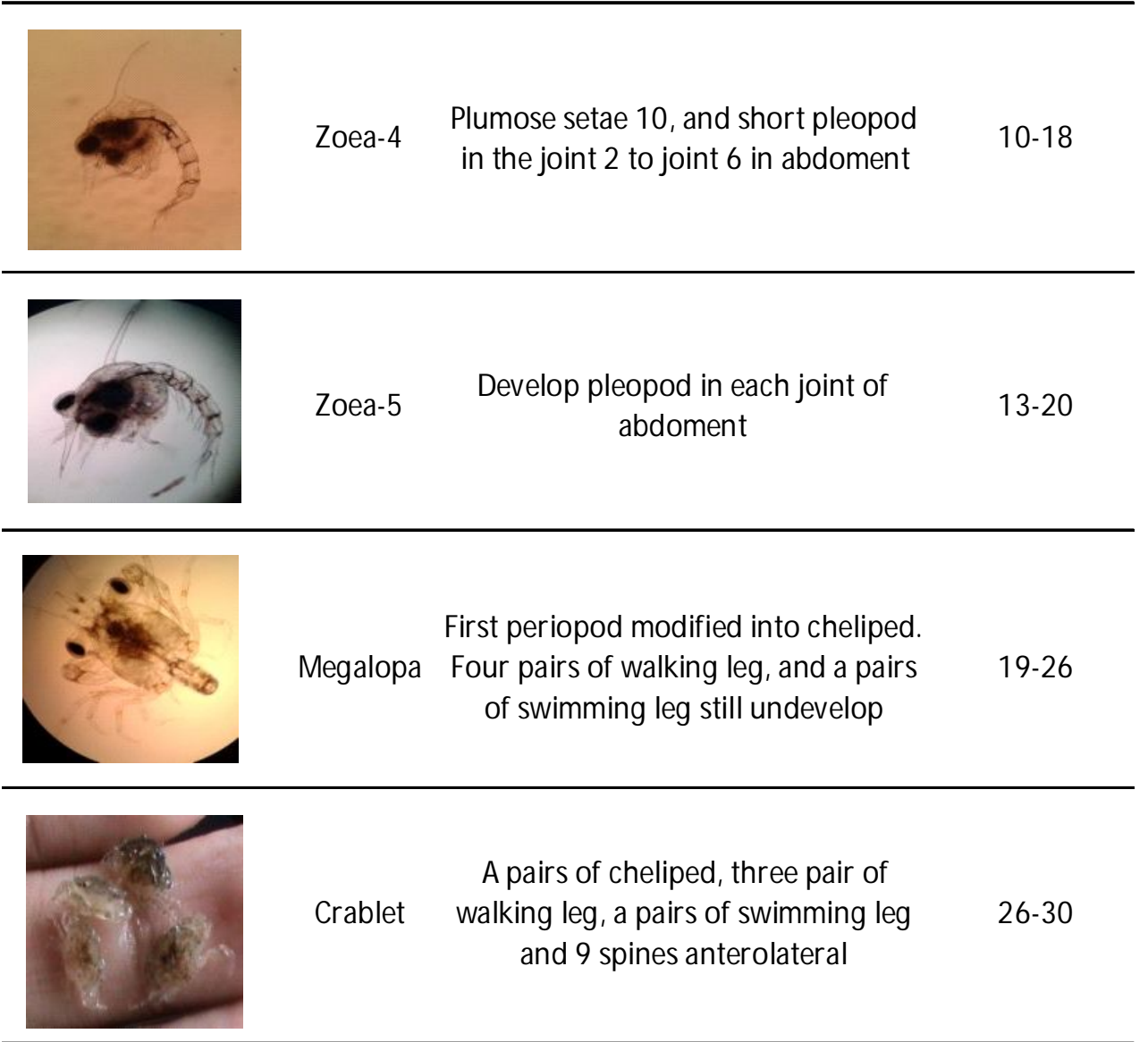

A pairs of cheliped, three pair of

Crablet walking leg, a pairs of swimming leg

$26-30$ and 9 spines anterolateral 
Table 2. Percentages of the survival rate of mud crab $\mathrm{S}$. tranquebarica larvae feed with different dosages of supplemented artificial commercial feed

\begin{tabular}{cccccc}
\hline & \multicolumn{5}{c}{ Percentage survival (\%) from zoea-1 to zoea-5 } \\
\cline { 2 - 6 } Treatments & $\begin{array}{c}\text { Zoea-1 } \\
\text { (1 dph })\end{array}$ & $\begin{array}{c}\text { Zoea-2 } \\
\text { (6 dph) }\end{array}$ & $\begin{array}{c}\text { Zoea-3 } \\
\text { (9 dph) }\end{array}$ & $\begin{array}{c}\text { Zoea-4 } \\
\text { (13 dph) }\end{array}$ & $\begin{array}{c}\text { Zoea-5 } \\
\text { (16 dph) }\end{array}$ \\
\hline A & 100 & $49.9 \pm 2.5^{\mathrm{a}}$ & $40.1 \pm 2.3^{\mathrm{b}}$ & $38.3 \pm 3.5^{\mathrm{b}}$ & $32.9 \pm 3.3^{\mathrm{a}}$ \\
B & 100 & $46.1 \pm 3.4^{\mathrm{b}}$ & $40.6 \pm 3.4^{\mathrm{b}}$ & $38.2 \pm 3.9^{\mathrm{b}}$ & $29.1 \pm 3.6^{\mathrm{a}}$ \\
C & 100 & $51.1 \pm 3.2^{\mathrm{a}}$ & $36.5 \pm 1.6^{\mathrm{a}}$ & $35.9 \pm 1.5^{\mathrm{a}}$ & $32.9 \pm 2.2^{\mathrm{a}}$ \\
D & 100 & $47.6 \pm 4.3^{\mathrm{a}}$ & $39.3 \pm 4.2^{\mathrm{b}}$ & $35.7 \pm 2.8^{\mathrm{a}}$ & $32.0 \pm 2.2^{\mathrm{a}}$ \\
\hline
\end{tabular}

Note: $\quad$ Means with different superscripts in the same column are significantly different at $P<0.05$ (Tukey test). Supplementation of artificial feed at: A). $0.5 \mathrm{mg} / \mathrm{L} / 2$ days, B). $0.75 \mathrm{mg} / \mathrm{L} / 2$ days, C). $1.0 \mathrm{mg} / \mathrm{L} / 2$ days, and D). $1.25 \mathrm{mg} / \mathrm{L} / 2$ days.

At day 3 ph most larvae still remained at the zoea1 stage. At day 6 ph, the LDI value (approx. 2) indicated that almost $100 \%$ of larvae were at the zoea- 2 stage (Figure 2). At day 9 ph, day 13 ph and day 16 ph the larvae population in all treatments were dominated by zoea- 3 stage, zoea- 4 stage and zoea- 5 stage respectively, where the LDI value of about 3,4 , and 5 , respectively. The microbound artificial diet was applied at varies dosages in the treatments namely; $0.5 \mathrm{mg} / \mathrm{L} / 2$ days (A); $0.75 \mathrm{mg} / \mathrm{L} / 2$ days (B); $1.0 \mathrm{mg} / \mathrm{L} / 2$ days (C); and $1.25 \mathrm{mg} / \mathrm{L} / 2$ days (D) and it was given from larvae at the stage of zoea-3 until develop to megalopa stage in this research. However, the LDI values in all stages of larvae statistically analysis there were no significantly difference $(P>0.05)$ among treatments. Contrary, the MOI values of larvae supple- mented with microbound artificial diet at $0.5 \mathrm{mg} / \mathrm{L} / 2$ days (A) and $0.75 \mathrm{mg} / \mathrm{L} / 2$ days (B) statistically analysis were showed significantly higher $(P<0.05)$ compared to the MOI value at the larvae supplemented microbound artificial diet at $1.0 \mathrm{mg} / \mathrm{L} / 2$ days (C) and $1.25 \mathrm{mg} / \mathrm{L} / 2$ days (D). Despite the higher MOI values obtained in treatment $A$ and $B$, the highest crablet production was obtained in treatment $D$. It seemed that feed supplementation at $1.25 \mathrm{mg} / \mathrm{L} / 2$ days (treatment D) caused high vitality of megalopa and more megalopa successfully develop to thecrablet stage. Sheen \& Wu (1999) reported that megalopa stage of S. serrata required a diet containing 5.3\%13.8\%lipid and $48 \%$ protein which are lower than the lipid and protein contents in the microbound artificial feed supplemented to the larvae zoea-3 to megalopa of $S$.

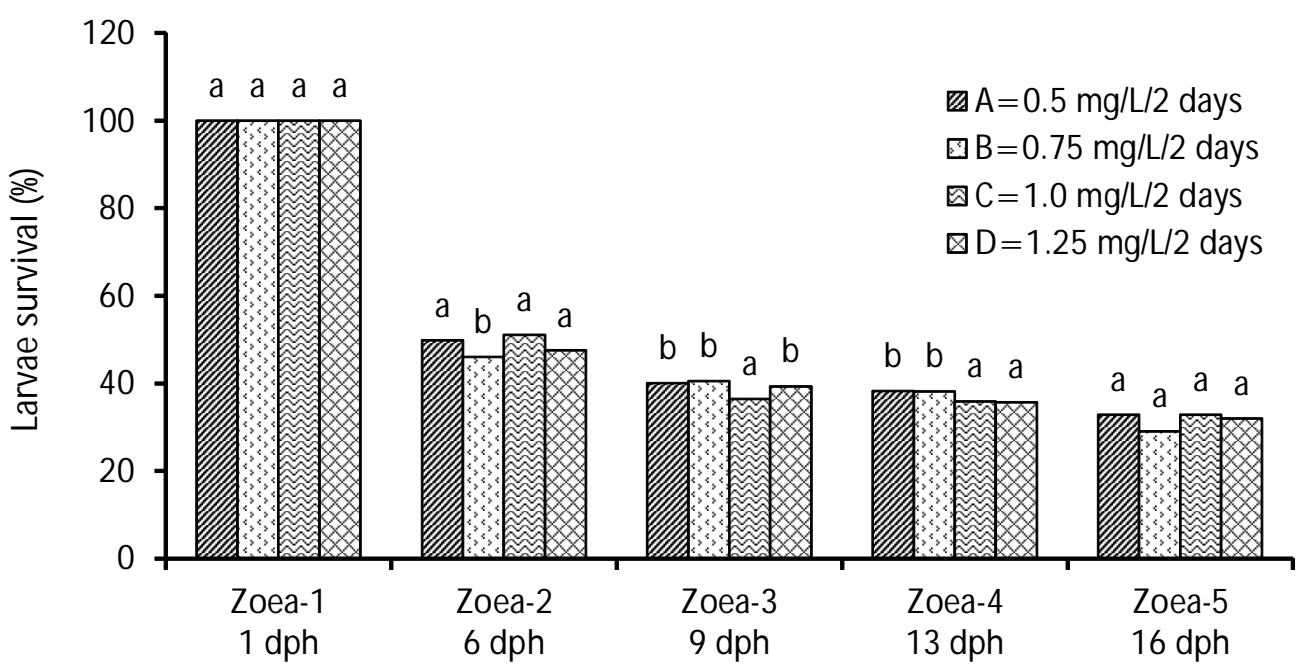

Figure 2. Larvae development indices (LDI) of S. tranquebarica larvae fed with supplemented commercial feed. (Supplementation of artificial feed at A). 0.5 $\mathrm{mg} / \mathrm{L} / 2$ days, B). $0.75 \mathrm{mg} / \mathrm{L} / 2$ days, C). $1.0 \mathrm{mg} / \mathrm{L} / 2$ days, and D). $1.25 \mathrm{mg} / \mathrm{L} / 2$ days). 
tranquebarica in this research. The protein, fat, fiber and water contents of the microbound artificial feed used in this research were $\geq 52 \% 14.5 \% \leq 3 \%$ and $10 \%$ respectively.

The occurrences of megalopa stage in the rearing tanks at day 18 ph were observed in treatment $A, B$, and $C$ with the $\mathrm{MOI}$ value of $0.02(\mathrm{~A}), 0.025$ (B), 0.02 (C). In treatment $D$, no megalopa was detected at day $18 \mathrm{ph}$. At day $19 \mathrm{ph}$, the highest $\mathrm{MOI}$ value obtained in treatment $B(0.40)$, followed by treatment $C(0.17)$, $A(0.14)$ and $D(0.13)$. At day $20 \mathrm{ph}$, more numbers of megalopa occurred in all treatments indicated by the increase of $\mathrm{MOI}$ values to $0.71(\mathrm{~A}) ; 0.8(\mathrm{~B}) ; 0.28(\mathrm{C})$; 0.41 (D). At day $21 \mathrm{ph}$, the $\mathrm{MO}$ O values were stabilized at $0.71(\mathrm{~A}) ; 0.88(\mathrm{~B}) ; 0.43$ (C) and 0.45 (D) (Table 4).

The highest crablet D-7 production was obtained by treatment $D(644.0 \pm 23$ ind./tank) and showed significant difference $(P<0.05)$ with treatment $A$ (550.0 \pm 30.0 ind./tank), but no significant difference ( $P>0.05)$ with treatment $C(631.0 \pm 51.0$ ind./tank) and B (625.0 22.0 ind./tank) (Table 4).

The larval development of $\mathrm{S}$. tranquebarica in this research was fast, reaching megalopa stage at day 18 ph. In authors' earlier study, it was found that larvae development of $\mathrm{S}$. olivacea reached megalopa stage at day 21 ph (Gunarto et al., 2016). Different stocking densities of larvae in the rearing tanks contribute to the accelerated larval development. In this research, the larvae stocking density was only 100 ind./L, while for S. olivacea, the larvae stocking density was 400 ind./L. In the S. olivacea larvae rearing, the highest of $\mathrm{MOI}$ value $(0.294)$ was obtained at the fourth day (day $25 \mathrm{ph}$ ) and resulting in the total crablet production per tank of only $191 \pm 16$ ind. In this research using larvae S. tranquebarica, the MOI value at the fourth day (day $22 \mathrm{ph}$ ) ranged between 0.43-0.88 with the crablet production per tank between 550-644 ind.

\section{Activity of Enzyme Amylase, Protease, and Lipase}

The activity of amylase enzyme in larvae from zoea1 to zoea-4 was low, but increased significantly in zoea-5. The activity of protease enzyme was higher compared with the activity of amylase enzyme in zoea1 larvae. However, at zoea-3, the activity of protease enzyme was decreased and showed lower value compared to the activity of amylase enzyme. At zoea-5, the activity of protease and amylase enzymes reached their highest values. Similarly, lipase enzyme activity was also low in larvae of zoea-1 and zoea-2 stage before significantly increased at zoea-3 and zoea- 4 . The lipase enzyme activity decreased again in zoea- 5 stage (Table 5).

Serrano \& Traifalgar (2012) had confirmed that S.serrata larva from zoea-3 to megalopa stage produced higher amylase and leucine aminopeptidase in order to digest artificial feed in the stomach.

The activity of amylase, lipase dan protease enzymes in larvae of S. paramamosain varies depend on larval stage development (Hong et al., 1995). In this research, the amylase enzyme activity in larvae of zoea-1 to zoea-4 stage was low but increased significantly in zoea-5. This might be the evidence that the early larvae stage of mud crab is a real carnivorous. The carnivorous larvae exhibited low levels of enzyme activity but compensating it by extending retention time of high energy food to maximize assimilation efficiency (Vay et al., 2001). When larvae reached zoea-5 stage, the feeding behavior shifted to omnivorous and at the same times, the activity of amylase enzyme increased sharply. Futhermore, Serrano (2012), reported that the increase of amylase enzyme activities in S. serrata larvae occurred from zoea-4 to megalopa stage. However, at crablet stage, the activity of amylase enzyme decreased dras-

Table 3. Megalopa occurrence indices (MOI) values and crablet production from the mud crab S. tranquebarica larvae fed with supplementation of artificial feed.

\begin{tabular}{cccccc}
\hline \multirow{2}{*}{ Treatments } & \multicolumn{5}{c}{$\begin{array}{c}\text { Megalopa occurrences indices and } \\
\text { crablet-D-7 production (ind.tank) }\end{array}$} \\
\cline { 2 - 6 } & $\mathbf{1 8} \mathbf{d p h}$ & $\mathbf{1 9} \mathbf{d p h}$ & $\mathbf{2 0} \mathrm{dph}$ & $\mathbf{2 1} \mathbf{d p h}$ & Crablet D-7 (35 dph) \\
\hline A & $0.020^{\mathrm{b}}$ & $0.14^{\mathrm{a}}$ & $0.71^{\mathrm{b}}$ & $0.71^{\mathrm{b}}$ & $550.0 \pm 30.0^{\mathrm{a}}$ \\
B & $0.025^{\mathrm{b}}$ & $0.40^{\mathrm{b}}$ & $0.60^{\mathrm{b}}$ & $0.88^{\mathrm{b}}$ & $625.0 \pm 22.0^{\mathrm{ab}}$ \\
C & $0.020^{\mathrm{b}}$ & $0.17^{\mathrm{a}}$ & $0.28^{\mathrm{a}}$ & $0.43^{\mathrm{a}}$ & $631.0 \pm 51.0^{\mathrm{ab}}$ \\
D & $0.001^{\mathrm{a}}$ & $0.13^{\mathrm{a}}$ & $0.41^{\mathrm{a}}$ & $0.45^{\mathrm{a}}$ & $644.0 \pm 23.0^{\mathrm{b}}$ \\
\hline
\end{tabular}

Note: Means with different superscripts in the same column are significantly different at $\mathrm{P}<0.05$ (Tukey test). Supplementation of artificial feed at: A). $0.5 \mathrm{mg} / \mathrm{L} / 2$ days, B). 0.75 $\mathrm{mg} / \mathrm{L} / 2$ days, $\mathrm{C}) .1 .0 \mathrm{mg} / \mathrm{L} / 2$ days, and $\mathrm{D}) .1 .25 \mathrm{mg} / \mathrm{L} / 2$ days. 
Table 4. The activity of amylase, protease, and lypase enzymes in different larval stages of mud crab S. tranquebarica

\begin{tabular}{cccc}
\hline Larval stage & $\begin{array}{c}\text { Amylase } \\
(\mu / \mathrm{mL} / \text { minute })\end{array}$ & $\begin{array}{c}\text { Protease } \\
(\mu / \mathrm{mL} / \text { minute })\end{array}$ & $\begin{array}{c}\text { Lypase } \\
(\mu / \mathrm{mL} / \text { minute })\end{array}$ \\
\hline Zoea-1 & 0.019 & 0.087 & 0.021 \\
Zoea-2 & 0.082 & 0.078 & 0.079 \\
Zoea-3 & 0.076 & 0.021 & 0.113 \\
Zoea-4 & 0.072 & 0.016 & 0.145 \\
Zoea-5 & 0.234 & 0.867 & 0.017 \\
\hline
\end{tabular}

tically. Futhermore, Jonhston et al. (2004) reported that in larvae of spiny lobster, Jasus edwardsii, the total concentration of amylase enzyme also increased according to the increase of the larval age.

The enzymes existed in the digestive system of larvae could also come from the enzyme found in natural food such as rotifer and artemia through their autolysis or zymogen to support the work of digestive systems (Kumlu \& Jones, 1995). Therefore, high enzyme activity is usually observed in the early stage of larvae fed with live food supplementation. In larvae of zoea-1 stage, the activity of protease enzyme was higher than that of amylase enzyme. The activity of protease enzyme decreased slightly from zoea1 to zoea-4 but then increased sharply at zoea-5. This might indicate that the introduction of a new diet into the larvae will not automatically increase the enzyme activity in the digesting system. It takes time for the larvae and its digestive system to adapt to the new diet. Jonhston et al. (2004) stated that a high activity of protease enzyme was correlated with the high protein content in their diet. The high activity of amylase and protease enzymes in zoea-5 larvae might be a response to the introduction of artificial feed with diet composition of fiber/carbohydrate and protein $(52 \%$.

The increases of lipase enzyme activity at zoea-3 and zoea-4 after leveling off during zoea-1 and zoea2 stages may be another indication of the need for more lipid at these larval stages. However, the lipase activity decreased again in zoea-5 stage (Table 5) suggesting that more lipid was required by larvae after larvae attained zoea-3.

The highest crablet production $(644.0 \pm 23.0$ ind./ tank) was obtained in treatment $D$ with $1.25 \mathrm{mg} / \mathrm{L} / 2$ days of supplemented feed and showed not significantly different $(P>0.05)$ with treatment $B$ (625.0 \pm 22.0 ind./tank) and C (631.3 \pm 50.91 ind./tank), but significantly different $(P<0.05)$ with treatment $A$ (550.0 \pm 30.0 ind./tank). Besides the feeding regime and nutritional quality of the life feed, crablet production was also affected by the unsynchronized molting from zoea-5 to megalopa (Suprayudi et al., 2012). Megalopa were found grazing on zoea-5 in the tanks, thus resulting in the low survival rate of crablet D-1. Lowering the megalopa stocking density (thinning) by separating the population into two or three tanks was able to reduce cannibalism and thus enhance the crablet production. Based on the result of the research, the authors suggest that the diet of mud crab larvae could be supplemented with artificial commercial feeds when the larvae are at zoea-3 to megalopa stage with suggested dosages between $0.75-1.25 \mathrm{mg} / \mathrm{L} / 2$ days.

The total organic matter was relatively high. There was no clear relation to the dosages of the supplemented diet i.e.: $A=51.3 \mathrm{mg} / \mathrm{L}, \mathrm{C}=48.8 \mathrm{mg} / \mathrm{L}, \mathrm{B}=$ $44.4 \mathrm{mg} / \mathrm{L}$ dan $\mathrm{D}=43.8 \mathrm{mg} / \mathrm{L}$. The same pattern was also observed in Vibrio population. Interestingly, the highest Vibrio sp. population of $10^{3} \mathrm{cfu} / \mathrm{mL}$ was observed in treatment A where the highest of TOM also occurred (Table 6). The high Vibrio population was believed to have contributed to producing the lowest crablet production in treatment $A$.

\section{CONCLUSION}

This research concludes that the supplementation of artificial commercial feed in the larval diet of $\mathrm{S}$. tranquebarica can be applied at the dosages of 0.75 $1.25 \mathrm{mg} / \mathrm{L} / 2$-days given from zoea-3 until the end of megalopa stage.

\section{ACKNOWLEDGMENTS}

This research is funded by the Aquaculture Research Program DIPA 2016, Research Institute for Coastal Aquaculture and Fisheries Extension, Maros, Ministry of Marine Affairs and Fisheries. We would like to thank Masyita Makmur, Sainal, and Risal for their assistance during the research. 
Table 5. The average of water quality parameters and Vibrio sp. population from the rearing tank for larva S. tranquebarica feed with supplemented artificial commercial feed

\begin{tabular}{|c|c|c|c|c|}
\hline Treatments & Amonium (mg/L) & Nitrite (mg/L) & TOM (mg/L) & Vibrio sp. $(\log \mathrm{cfu} / \mathrm{mL})$ \\
\hline$A$ & $0.58 \pm 0.01$ & $0.45 \pm 0.07$ & $51.3 \pm 15.04$ & $3.95 \pm 0.31$ \\
\hline B & $0.97 \pm 0.007$ & $0.32 \pm 0.007$ & $44.4 \pm 0.007$ & $3.91 \pm 0.40$ \\
\hline C & $0.91 \pm 0.20$ & $0.41 \pm 0.01$ & $48.8 \pm 7.96$ & $3.78 \pm 0.36$ \\
\hline D & $0.88 \pm 0.24$ & $0.49 \pm 0.07$ & $43.8 \pm 0.88$ & $3.84 \pm 0.08$ \\
\hline
\end{tabular}

Supplementation of artificial feed at: A). $0.5 \mathrm{mg} / \mathrm{L} / 2$ days, B). $0.75 \mathrm{mg} / \mathrm{L} / 2$ days, C). $1.0 \mathrm{mg} / \mathrm{L} / 2$ days, and D). $1.25 \mathrm{mg} / \mathrm{L} / 2$ days

\section{REFERENCES}

Anuar, H., Hai, T.N., Anil, C., \& Sukumaran, M. (2011). Preliminary study on the feeding regime of laboratory reared mud crab larva, Scylla serrata (Forsskal, 1775). Word Applied Sciences Journal, 14(11), 1651-1654.

Baylon, J.C. (2011). Survival and development of larvae and juveniles of the mud crab Scylla olivacea Forskal (Crustacea: Decapoda: Portunidae) at various temperatures and salinities. Philipp Agric Scientist, 94(2), 195-204.

Chen, H.C., \& Cheng, H. (1985). Studies on the larval rearing of serrated crab, Scylla serrata: I. Combined effects of salinity and temperature on the hatching, survival, and growth of zoeae, J. Fish. Soc. Taiwan, 12, 70-77.

Clesceri, L.S., Greenberg, A.E., \& Eaton, A.D. (2005). Standard methods for the examination of water and wastewater. American Public Health Association, Washington. USA, p. 4-103.

Genodepa, J., Southgate, P.C., \& Zeng, C. (2004). Diet particle size preference and optimal ration for mud crab, Scylla serrata, larvae fed microbound diet. Aquaculture, 230, 493-505.

Gunarto, \& Herlinah. (2015). Level of crablet production in mangrove crab Scylla paramamosain with feeding enrichment using hufa and vitamin $\mathrm{C}$ on larvae stages. J. Ilmu dan Teknologi Kelautan Tropis, 7(2), 511-520.

Gunarto, Parenrengi, A., \& Septiningsih, E. (2016). Crablet of mud crab Scylla olivacea production from the different stages of larvae fed Artemia nauplii enriched using Nannochloropsis sp. Hasanuddin University: International Journal of Agriculture System, 4(2), 132-146.

Gunarto, \& Sulaeman. (2017). Rearing of mud crab, Scylla tranquebarica larvae with different stocking densities. Jurnal Omni Akuatika, 13(2), 190-198.

Hamasaki, K., Suprayudi, M.A., \& Takeuchi, T. (2002). Effects of dietary N-3 HUFA on larval morphogen- esis and metamorphosis to the megalops in the seed production of the mud crab, Scylla serrata (Brachiura: Portunidae). Suisanzoshoku, 50(3), 333340.

Hong, T., Li, S., Guizhong, W., \& Lin, Q. (1995). The experimental studies on the digestive enzyme activities in the larvae of the mud crab Scylla serrata Forskal. J. Xiamen Univ. (Nat Sci), 34, 88-93.

Holme, M-H. (2008). Toward development of a formulated diet for mud crab (Scylla serrata) larvae, with emphasis on lipid nutrition. Thesis submitted for the degree of Doctor of Philosophy in the School of Marine \& Tropical Biology, James Cook University. Australia, $165 \mathrm{pp}$.

Ikhwanuddin, M.Z., Bachok, M.G., Hilmi, G.A., \& Zakaria, M.Z. (2010). Species diversity, carapace width-body weight relationship, size distribution and sex ratio of mud crab, genus Scylla from Setiu Wetlands of Terengganu Coastal waters, Malaysia. J. Sustainability Sci. Manage, 5, 97-109.

Johnston, D., Ritar, A., Thomas, C., \& Jeffs, A. (2004). Digestive enzyme profiles of spiny lobster Jasus edwardsii phyllosoma larvae. Marine Ecology Progress Series, 275, 219-230.

Keenan, C.P. (1999). Aquaculture of mud crab, genus Scylla past, present, and future. In Mud Crab Aquaculture and Biology. ACIAR Proceedings, ACIAR, Canberra. Australia, 78, 9-13.

Kumlu, M., \& Jones, D.A. (1995). The effect of live and artificial diets on growth, survival and trypsin activity in larvae of Penaeus indicus. J. World Aquac. Soc., 26, 406-415.

Quinitio, E.T., Parado-Estepa, F.D., Millamena, O.M., Rodriguez, E., \& Borlongan, E. (2001). Seed production of mud crab Scylla serrata juveniles. Asian Fisheries Science, 14, 161-174.

Sheen, S.S., \& Wu, S.W. (1999). The effects of dietary lipid levels on the growth response of juvenile mud crab, Scylla serrata. Aquaculture, 175(1), 143153. 
Serrano, A.E.Jr., \& Traifalgar, R.F. (2012). Ontogeny and induction of digestive enzymes in Scylla serrata larvae fed live or artificial feeds or their combination. AACL Bioflux, 5(3), 101-111.

Serrano, A.E.Jr. (2012). Ontogeny of endogenous and exogenous amylase and total protease activities in mud crab, Scylla serrata larvae fed live food. European Journal of Experimental Biology, 2(5), 15781584.

Suprayudi, M.A., Takeuchi, T., \& Hamazaki, K. (2012). Phospholipids effect on survival and molting synchronicity of larvae mud crab Scylla serrata. Hayati Journal of Bioscience, 19(4), 163-169.

Thirunavukkarasu, N., Nesakumari, S.A., \& Shanmugam, A. (2014). Larva rearing and seed production of mud crab Scylla transquebarica (Fabricius, 1798). International Journal of Fisheries and Aquatic Studies, 2(2), 19-25.
Truong, T.N., Mathieu, W., Tran, C.B., Hoang, P.T., Nguyen, V.D., \& Sorgeloos, P. (2007a). Improved techniques for rearing mud crab Scylla paramamosain (estampador 1949) larvae. Aquaculture Research, 38, 1539-1553.

Truong, T.N., Mathieu, W., Stijn, V., Quach, T.V., \& Sorgeloos, P. (2007b). Influence of highly unsaturated fatty acids in live food on larviculture of mud crab, Scylla paramamosain (Estampador, 1949). Aquaculture Research, 38, 1512-1528.

Vay, L.L. Jones, D.A., Puello-Cruz, A.C., Sangha, R.S., $\&$ Ngamphongsai, C. (2001). Digestion in relation feeding strategies exhibited by crustacean larvae. Comparative Biochemistry and Physiology A, 128(3), 623-630.

Watanabe, T., Kitajima, C., \& Fujita, S. (1983). Nutritional values of life food organisms used in Japan for the mass propagation of fish: a review. Aquaculture, 34, 115-143. 